\title{
Correlates of Entrepreneurial Behaviour of Tribal Farmers in Senapati District of Manipur, India
}

\author{
S. Kareini Kayina*, Daya Ram, M. Deepa Devi and Wangkhem Miranda \\ Department of Extension Education, College of Agriculture, Central Agricultural University \\ Imphal-795004 Manipur (India) \\ *Corresponding author
}

\section{A B S T R A C T}

\section{Keywords \\ Entrepreneurial behaviour, Farm decision making, Risk-taking willingness, Leadership ability, Cosmopoliteness. \\ Article Info \\ Accepted: \\ 10 June 2018 Available Online: 10 July 2018}

\begin{abstract}
The present study was conducted during the year 2017-18 in Senapati District, Manipur. Out of total sixteen districts in the state, Senapati District was selected as it comprised of ST communities. One sub-division i.e. Mao-Maram was selected out of seven sub-division keeping in view of highest tribal population and population density. A multistage sampling procedure was followed. A sample of tribal farmers consisting 125 respondents was selected from five villages of the sub-division based on simple random sampling. The statistical methods and test such as frequency, percentage, mean, standard deviation and correlation were used for the analysis of data. Correlation analysis between entrepreneurial behaviour and characteristics of the tribal farmers revealed that variables such as education, occupation, size of land holding, annual income, social participation, mass media exposure, extension participation and level of aspiration were found positively significant to access the entrepreneurial behaviour of the tribal farmers at 0.05 level of probability.
\end{abstract}

\section{Introduction}

According to L.P.Vidyarthi tribe is a social group with a definite territory, common name, common descent, common culture, the behavior of an endogamous group, common taboos, existence of distinctive social and political system, and full faith in leaders and self- sufficiency in their distinct economy (Vidyarthi, 1981). According to India's most recent census in 2011 Schedule Tribes comprise $8.6 \%$ of the population. The incredibly increasing human and animal population, the pressured environment, the consumer markets and economics, the industrial development and other several related factors has resulted in the exploitation of natural resources. This has resulted in the degradation of forests, several environmental problems and has consequently led to the fall off of homeland of native tribal. The primitive methods of farming, agriculture, shifting cultivation and exploitation of the forest produce by the millions of people living 
within and out of the forest have led to major forest loss. The main problem in the society is that there is no proper awareness and understanding of the tribal people. In government point of view, even the government has taken a lot of schemes benefiting to them; the whole benefits did not reach them properly. Most bankers hesitate to give loans to them because they don't have proper income and status in the society. The objectives of the study are to identify the independent variable which promote or inhibits the entrepreneurial behaviour of tribal farmers in Senapati District of Manipur.

\section{Materials and Methods}

The present investigation was carried out in Manipur during 2017-18. An ex-post facto research design was employed for the study. A multiple stage sampling procedure was followed. Out of total sixteen districts in the state, Senapati District was selected as it comprised of ST communities. One subdivision i.e. Mao-Maram was selected out of seven sub-division keeping in view of highest tribal population and population density. From the selected sub-division, five villages were randomly selected, applying the criterion of the maximum tribal population. Thus, total five villages were selected. From each selected village, 25 respondents were selected randomly. Thus, a total sample of tribal farmers consisting of 125 respondents was randomly selected from five villages of the sub-division based on simple random sampling. The primary data were collected using pre-tested structured interview schedule. Keeping in view of the objectives, the independent variables were selected based on the available literature and opinions of experts in the field of extension. The exploratory and analytical research design adopted for this study and the data were analyzed by using appropriate statistical methods.

\section{Results and Discussion}

To measure the extent of the entrepreneurial behaviour of the tribal farmers, various dimensions of entrepreneurship were identified. The measure of the entrepreneurial behaviour of the tribal farmers was taken as the sum of scores obtained by the respondents viz., farm decision making, achievement motivation, innovation proneness, economic motivation, risk-taking willingness, leadership ability and cosmopoliteness. The total score received by each respondent was converted to percent score to bring it to a uniform base and these scores were treated as final scores for further analysis and interpretation.

\section{Farm decision making}

It is evident from the Table 1, that majority of the respondents $(56.00 \%)$ belonged to medium farm decision-making category followed by low (25.60\%) and low (18.40\%) decision making categories, respectively. This might be due to their medium annual income and education level. The other possible reason might be that decision making in farming, especially in India conditions is very difficult due to ever changing agro-climatic conditions and lack of stabilized price policy (Chandrapaul, 1998 and Suresh, 2004).

\section{Achievement motivation}

It is apparent from the Table 1 that, $(54.40 \%)$ of respondents belong to medium achievement motivation category, whereas $(23.20 \%)$ of them belong to high achievement motivation category and rest of the $(22.40 \%)$ belong to low achievement motivation category. The probable reason that majority of respondents had medium economic motivation because they have better exposure with various private companies and close interaction with extension personnel. Other reason may be due to surrounding environment like neighbours, 
relatives, friends were having medium standard of living their income responsible for moderate economic motivation (Chauhan and Patel 2003).

\section{Innovation proneness}

The results from Table 1 indicated that majority $(68.00 \%)$ of the respondents had medium innovativeness followed by high (19.20\%) and low (12.80\%) innovativeness, respectively. The medium innovativeness of tribal farmers might be due to their age of the respondents which have restricted them to go always for new things and their higher level of education. 52.00 per cent were at medium level of cosmopoliteness indicates their contact with outside community. All these factors might have contributed for their medium level of innovativeness (Bhagyalaxmi et al. (2003).

\section{Economic motivation}

The results presented in Table 1 indicated that $(14.40 \%)$ of respondents had high economic motivation, (70.40\%) of them had medium level of economic motivation and remaining $(15.20 \%)$ of them had low economic motivation. The probable reason that majority of respondents had medium economic motivation because they have better exposure with various private companies and close interaction with extension personnel. Other reason may be due to surrounding environment like neighbours, relatives; friends were having medium standard of living their income responsible for moderate economic motivation. (Chauhan and Patel 2003).

\section{Risk taking willingness}

It is evident from Table 1 that, $(42.40 \%)$ of the respondents belong to high risk taking ability, followed by $(40.00 \%)$ and $(17.60 \%)$ of them belonging to medium and low risk taking ability categories, respectively. The risk bearing capacity of individuals depend upon the personal, psychological, socio-economic characteristics. High risk bearing ability was due to younger age, good education and better economic condition of the respondents. This might be because contact with extension personnel by the respondents which might have increased the perception and confidence of the respondents about new technologies and to gain more income by taking risk all these factors might have inferred the respondents to be in high risk orientation (Bhagyalaxmi et al. 2003 and Suresh 2004).

\section{Leadership ability}

It is quite clear from Table 1 that, (48.80\%) of the respondents had medium leadership ability followed by high $(28.80 \%)$ leadership ability. However, only (22.40\%) of them belong to low leadership ability category. This may be due to majority were in middle age group, had high school education, had medium income level, other reason may be their extension participation and cosmopoliteness helps the farmers to adopt new agricultural practices earlier than others. In his social system, these kinds of farmers who are early adopters were consulted by fellow farmers for information and are readily accepted as leaders (Suresh 2004).

\section{Cosmopoliteness}

It is evident from Table 1 that, $(52.00 \%)$ of respondent had medium level of cosmopoliteness, followed by low $(27.20 \%)$ and high $(20.80 \%)$ level of cosmopoliteness, respectively. Cosmopoliteness is the degree to which a farmer is oriented outside his community to seek information. Majority fall under medium because due to their sound economic condition and education level and locally available of NGOs officials and low may be because of disinterest and illiteracy (Kashem and Hossain 1992). 
Table.1 Extent of entrepreneurial behaviour of the tribal farmers

\begin{tabular}{|c|c|c|c|c|}
\hline Sl.No. & $\begin{array}{c}\text { Dimension of } \\
\text { Entrepreneurial } \\
\text { Behaviour }\end{array}$ & $\begin{array}{c}\text { Classification of } \\
\text { Category }\end{array}$ & Frequency & Percentage \\
\hline 1. & Farm decision making & $\begin{array}{l}\text { Low } \\
\text { Medium } \\
\text { High }\end{array}$ & $\begin{array}{l}32 \\
70 \\
23\end{array}$ & $\begin{array}{l}25.60 \\
56.00 \\
18.40\end{array}$ \\
\hline 2. & $\begin{array}{l}\text { Achievement } \\
\text { Motivation }\end{array}$ & $\begin{array}{l}\text { Low } \\
\text { Medium } \\
\text { High }\end{array}$ & $\begin{array}{l}28 \\
68 \\
29\end{array}$ & $\begin{array}{l}22.40 \\
54.40 \\
23.20\end{array}$ \\
\hline 3. & Innovation Proneness & $\begin{array}{l}\text { Low } \\
\text { Medium } \\
\text { High }\end{array}$ & $\begin{array}{l}16 \\
85 \\
29\end{array}$ & $\begin{array}{l}12.80 \\
68.00 \\
19.20\end{array}$ \\
\hline 4. & Economic Motivation & $\begin{array}{l}\text { Low } \\
\text { Medium } \\
\text { High }\end{array}$ & $\begin{array}{l}19 \\
88 \\
18\end{array}$ & $\begin{array}{l}15.20 \\
70.40 \\
14.40\end{array}$ \\
\hline 5. & Risk-taking Willingness & $\begin{array}{l}\text { Low } \\
\text { Medium } \\
\text { High }\end{array}$ & $\begin{array}{l}22 \\
50 \\
53\end{array}$ & $\begin{array}{l}17.60 \\
40.00 \\
42.40\end{array}$ \\
\hline 6. & Leadership Ability & $\begin{array}{l}\text { Low } \\
\text { Medium } \\
\text { High }\end{array}$ & $\begin{array}{l}28 \\
61 \\
36\end{array}$ & $\begin{array}{l}22.40 \\
48.80 \\
28.80\end{array}$ \\
\hline 7. & Cosmopoliteness & $\begin{array}{l}\text { Low } \\
\text { Medium } \\
\text { High }\end{array}$ & $\begin{array}{l}45 \\
61 \\
19\end{array}$ & $\begin{array}{l}36.00 \\
48.80 \\
15.20\end{array}$ \\
\hline
\end{tabular}

Table.2 Correlation co-efficient between personal, socio-economic and psychological characteristics and entrepreneurial behaviour of the tribal farmers

\begin{tabular}{|c|l|c|}
\hline Sl. No. & \multicolumn{1}{|c|}{ Variable } & $\begin{array}{c}\text { Entrepreneurial Behaviour } \\
\text { Correlation coefficient ' } r \text { ' }\end{array}$ \\
\hline $\mathbf{1 .}$ & Age & $0.111^{\mathrm{NS}}$ \\
\hline $\mathbf{2 .}$ & Family size & $0.179^{\mathrm{NS}}$ \\
\hline $\mathbf{3 .}$ & Education & $0.688^{*}$ \\
\hline $\mathbf{4 .}$ & Occupation & $0.359^{*}$ \\
\hline $\mathbf{5 .}$ & Size of land holding & $0.349^{*}$ \\
\hline $\mathbf{6 .}$ & Annual income & $0.665^{*}$ \\
\hline $\mathbf{7 .}$ & Social participation & $0.610^{*}$ \\
\hline $\mathbf{8 .}$ & Mass media exposure & $0.584^{*}$ \\
\hline $\mathbf{9 .}$ & Extension participation & $0.654^{*}$ \\
\hline $\mathbf{1 0}$ & Level of aspiration & $0.658^{*}$ \\
\hline
\end{tabular}

"Significant at 0.05 levels of probability's and Non-significant 
Table.3 Distribution of respondents according to their Entrepreneurial Behaviour

\begin{tabular}{|c|c|c|}
\hline Category & Frequency & Percentage \\
\hline Low & 34 & 27.20 \\
\hline Medium & 65 & 52.00 \\
\hline High & 26 & 20.80 \\
\hline
\end{tabular}

Overall Entrepreneurial Behaviour of the tribal farmers

Table 3 reveals that, $(52.00 \%)$ of the respondents belonged to medium entrepreneurial behaviour category. Whereas $(27.20 \%)$ of them belonged to low entrepreneurial behaviour category and rest of them $(20.80 \%)$ belonged to high entrepreneurial behaviour category. The possible reason for medium entrepreneurial behaviour may be due to medium farm decision making, achievement motivation, and innovation proneness, and economic motivation, risk taking willingness, leadership ability, and cosmopoliteness. The possible reason for low entrepreneurial category may be low level of farm decision making, achievement motivation and cosmopoliteness. The possible reason for high entrepreneurial behaviour of big farmers might be due to their sound financial condition, family size and high level of aspiration to take risk and adopt new technologies besides high innovativeness, risk taking willingness and leadership ability ( Pandya 1997).

Correlation co-efficient between personal, socio-economic and psychological characteristics and entrepreneurial behaviour of the tribal farmers

From the examination of Table 2, the correlation coefficient of personal, socioeconomic and psychological characteristics of tribal farmers with their entrepreneurial behaviour can be observed that education, occupation, size of land holding, annual income, social participation, mass media exposure, extension participation and level of aspiration were found to be positively and significantly correlated to the extent of entrepreneurial behaviour of the tribal farmers.

It can be concluded that majority of the respondents $(52.00 \%)$ of the tribal farmers in Senapati District had medium extent of entrepreneurial behaviour, this was followed by $(27.20 \%)$ of the respondents that has low extent of entrepreneurial behaviour and rest $(20.80 \%)$ of the respondents had high extent of entrepreneurial behaviour. Education, occupation, size of land holding, annual income, social participation, mass media exposure, extension participation and level of aspiration were found to be positively and significantly correlated to the extent of entrepreneurial behaviour of the tribal farmers at 0.05 level of probability. It was observed that education emerged as the most significant characteristics in predicting the extent of entrepreneurial behaviour.

\section{Acknowledgement}

The authors acknowledge the contributions of S. Kareini Kayina, Daya Ram, M. Deepa Devi and Wangkhem Miranda, Department of Extension Education, College of Agriculture Central Agricultural University, Imphal, Manipur (India) for their technical support and valuable contributions to the manuscript.

\section{References}

Anitha, B. (2004). A study on entrepreneurial behaviour and market participation of 
farm women in Bangalore rural district of Karnataka. M.Sc. (Agri.) Thesis, Univ. Agri. Sci., Bangalore.

Bhagyalaxmi, K., Rao, G.V. and Reddy, S.M., (2003). Profile of the rural women micro-entrepreneurs. J. Res. Acharya N.G. Ranga Agricultural University, Hyderabad, 31(4): 51-54.

Chandramouli, P. (2005). A study on entrepreneurial behaviour of farmers in Raichur district of Karnataka. M.Sc. (Agri.) Thesis, Univ. Agric. Sci., Dharwad.

Chauhan, N.B. and Patel, R.C. (2003). Entrepreneurial uniqueness of poultry entrepreneurs. Rural India, 66(12): 236-239.

Kashem, M.A. and Hossain, M. (1992). Adoption behaviour of sugarcane growers. Indian Journal of Extension
Education, 28: 92-96.

Pandya, R. D. (1997). Entrepreneurial behaviour of inland fishermen. Journal of Extension Education, 8(2): 1718.

Ravi G. V. (2007). A study on entrepreneurial behavioural characteristics of SC and ST farmers of Gulbarga District. $M$. Sc. (Agri.) Thesis, Univ. Agric. Sci., Dharwad.

Suresh, (2004). Entrepreneurial behaviour of milk producers in Chittoor district of Andhra Pradesh - A critical study M.V.Sc. Thesis, Acharya N.G. Ranga Agri. Univ., Hyderabad.

Vidyarthi L.P. (1981). Tribal Development and its Administration, Concept Publishing Company, New Delhi, pp.12-14.

\section{How to cite this article:}

Kareini Kayina, S., Daya Ram, M. Deepa Devi and Wangkhem Miranda. 2018. Correlates of Entrepreneurial Behaviour of Tribal Farmers in Senapati District of Manipur, India. Int.J.Curr.Microbiol.App.Sci. 7(07): 1673-1678. doi: https://doi.org/10.20546/ijcmas.2018.707.197 